\title{
TEACHING SUSTAINABILITY ONLINE TO UNIVERSITY STUDENTS WITH THE USE OF INTERACTIVE PRESENTATION TOOLS: A CASE STUDY
}

\author{
Iryna Lytovchenko ${ }^{1}$ (corresponding author), Nataliia Yamshynska ${ }^{2}$, \\ Neonila Kutsenok ${ }^{3}$, Violeta Filatova ${ }^{4}$ \\ ${ }^{1,2,3}$ National Technical University of Ukraine "Igor Sikorsky Kyiv Polytechnic Institute”, \\ Kyiv, Ukraine \\ ${ }^{4}$ Kennesaw State University, Kennesaw, Georgia, United States \\ irinalyt@ukr.net
}

\begin{abstract}
The study was aimed to analyse the efficiency of teaching sustainability online at ESP classes. The participants of the study were 33 second-year technical university students who studied Sustainable Development issues with the use of interactive presentation platforms Thinglink and Padlet which employed different multimedia resources - text, pictures, sound, animation, video. The students' attitudes toward sustainability issues before and after the experimental learning was measured with the use of the sustainability consciousness questionnaire developed by Gericke, Boeve-de Pauw, Berglund and Olsson (2018). The analysis of changes in different parameters of engineering students' sustainability consciousness showed the feasibility and appropriateness of teaching sustainability in an ESP course. The students' answers showed an increase in their knowingness of issues of Sustainable Development and their more responsible environmental behaviour, which implies the importance of disseminating knowledge and educating people for building a sustainable future. Based on the results of our study, we can conclude that ESP is a course which can organically integrate sustainability topics into its curriculum and use a wide range of resources and materials about Sustainable Development, since the majority of them are in English and thus can contribute not only to Learning for Sustainability but also to language acquisition. The use of online presentation tools and a wide range of multimedia resources on their platforms makes the learning more interactive and motivating for students and stimulates them to active inquiry into sustainability issues.
\end{abstract}

Keywords: teaching sustainability; sustainability consciousness; engineering students; ESP; interactive presentation tools.

\section{Introduction}

Climate change, global warming, exhaustion of natural resources, deforestation, extinction of animals and plants, water, air and soil pollution, food shortages and other threats to the future of our planet demand new approaches to the environment and development. In conditions of the growing ecological crisis, the concept of Sustainable Development sounds particularly pertinent. One of the most well-known and commonly accepted definitions of Sustainable Development was made by the World Commission on Environment and Development (WCED) which defined it as “... a development that meets the needs of the present generation without compromising the ability of future generations to meet their own needs" (1987, p. 41).

Over the last few decades, a considerable volume of research has been devoted to environmental issues which caused changes in our understanding of the relationship between man and nature. The key role in raising awareness and disseminating principles of sustainable development was attributed to Education for Sustainable Development (Cotton et al., 2007; Biasutti \& Frate, 2017; Makrakis \& Kostoulas-Makrakis, 2012; Gericke et al., 2018; Lavrysh, Lytovchenko \& Lukianenko, 2020).

In literature (UNESCO, n.d.; Grosseck, Tîru \& Bran, 2019), Education for Sustainable Development is defined as a holistic approach, involving the integration of major sustainable development issues into all teaching and learning strategies. The UNESCO's (n.d.) definition also emphasises that "it requires participatory teaching and learning methods that motivate and empower learners to change their behaviour and take action for sustainable development. Education for Sustainable Development consequently promotes competencies like critical thinking, imagining future scenarios and making decisions in a collaborative way". As stated by Boeve-de Pauw et al. (2015), the UNESCO's (n.d.) definition includes two essential features of Education for Sustainable Development: the first deals with content, the second with pedagogy.

The primary aim of UNESCO is to ensure that by 2030 all learners acquire knowledge and skills necessary to promote sustainable development, including the promotion of human rights and freedoms, gender equality, culture of peace, respect of cultural diversity. "There is now an increased recognition at the

(C) Lytovchenko, I., Yamshynska, N., Kutsenok, N., Filatova, V. 2021. Published by Igor Sikorsky Kyiv Polytechnic Institute. This is an Open Access article distributed under the terms of the licence CC BY 4.0 
international policy level that education is essential to the advancement of sustainable development, with many countries committed to continuing to work to advance Education for Sustainable Development at the national and local levels" (Buckler \& Creech, 2014, p. 9). That is why the United Nations aims at "integrating the principles and practices of sustainable development into all aspects of education and learning, to encourage changes in knowledge, values and attitudes with the vision of enabling a more sustainable and just society for all” (Buckler \& Creech, 2014, p. 9).

In the context of our study, it is important to mention that particular emphasis by UNESCO is made on the role of higher education since the "reach and potential for influence" of this sector in "moving the world to sustainable development is significant" (Buckler \& Creech, 2014, p.114). Special attention is paid to further exploration of possibilities of online learning in the advancement of Education for Sustainable Development in higher education. UNESCO emphasises that the expansion of sustainability in higher education should not only take place through campus-based programmes but also through various models of distance and online learning which significantly expand the reach of institutions to students (Buckler \& Creech, 2014). We should also underline the role of ESP in raising students' Sustainable Development consciousness since this discipline provides numerous opportunities for integrating sustainability topics into its design, especially in view of the fact that the main resources and materials about Sustainable Development issues, including those created by the United Nations and UNESCO, are in English.

With that in mind, the purpose of our study was to analyse the efficiency of teaching sustainability online to engineering students with the use of interactive presentation tools (Thinglink and Padlet) at ESP classes.

\section{Methods}

Research design

To achieve the purpose of our research we used the quantitative research method which involved collecting data by means of a survey. The data analysis was conducted with the use of descriptive statistics which permitted summarizing and interpreting the data obtained.

\section{Participants}

The participants of the study were 33 second-year bachelor degree students (aged $18-19$ years) of the National Technical University of Ukraine "Igor Sikorsky Kyiv Polytechnic Institute". The study was carried out in the first semester of 2020-2021 academic year. Before the beginning of the experiment, the students were informed about the anonymity and confidentiality of data collection and observation, the possibility to stop the participation at any time without any academic consequences.

\section{Instruments and procedure}

The Likert scale was chosen to measure the respondents' attitudes toward sustainability issues before and after the experimental learning since this instrument is widely used by researchers in education for that kind of purposes. We used the sustainability consciousness questionnaire (short version -27 questions) developed by Gericke, Boeve-de Pauw, Berglund and Olsson (2018) based on UNESCO's (Buckler \& Creech, 2014) definition of sustainable development to measure individuals' environmental, social and economic knowingness, attitudes and behaviour. Thus, the questionnaire consists of three sections: sustainability knowingness ( 9 items), sustainability attitudes ( 9 items) and sustainability behaviour ( 9 items) and covers the 15 subthemes of sustainable development defined by UNESCO (Buckler \& Creech, 2014). We found this questionnaire particularly appropriate for our purposes due to its validity and reliability and also because it was initially used by its creators to survey respondents of the same age range (18-19 years) as our students. The items are presented using a Likert scale ranging from 1 "strongly disagree" to 5 "strongly agree". The same questionnaire was used before and after the experimental learning so that we could find out if the experimental learning made any impact on the students' sustainability consciousness.

Our study consisted of three stages. At the first stage, the Gericke, Boeve-de Pauw, Berglund and Olsson (2018) questionnaire was used to measure the students' sustainability consciousness and then they were introduced to the basic information about Sustainable Development and the Goals of Sustainable Development defined by UNESCO (https://www.un.org/sustainabledevelopment/sustainable-developmentgoals/) with further discussion, which motivated the students' inquiry-based activity and helped increase their interest in the topic of discussion.

At the second stage, students were actively involved in research activities in order to expand their knowledge about sustainable development and awareness of its importance for humanity. At this stage, students were asked to identify topics for their individual Webquests, in which they had to independently explore those aspects or problems of sustainable development that were of greatest interest for them. The results of the Webquests had to be presented to the class with the use of interactive presentation tools 
Thinglink and Padlet. The interactive mode of presentations using multimedia resources (text, pictures, sound, animation, video) stimulated students' discussion of the problems, made learning more active and interesting, engaged them into further research activities.

At the third stage, students were re-surveyed using the same questionnaire that was offered to them at the first stage, in order to analyse and compare the results with those obtained before the start of experimental learning. This made it possible to find out whether experimental learning helped to raise students' sustainability consciousness.

Data collection and analysis tools

To collect the data we used Google Forms application. The questionnaire included 27 questions with the following answer choices: Strongly disagree, Disagree, Neither agree nor disagree, Agree, Strongly agree. To analyse the data, we used Microsoft Excel and SPSS Statistics 20 software.

\section{Results}

The results of the survey of students before and after the experimental learning were collected using the Likert scale questionnaire aimed to assess the effectiveness of teaching sustainability, in particular its impact on respondents' knowingness, attitudes and behaviour in environmental, social and economic spheres of sustainable development (See Table 1).

Sustainability knowingness

In this category we can observe a positive change in indexes of students' knowingness after the experimental learning, which is evidenced by the Median value increase in items 1 (Reducing water consumption is necessary for sustainable development), 2 (Preserving the variety of living creatures is necessary for sustainable development), 5 (Respecting human rights is necessary for sustainable development) and 9 (Wiping out poverty in the world is necessary for sustainable development). The IQR which equalled to 1 or 2 before and after the experiment showed that there was no significant divergence in the respondents' opinions.

In the "environmental" block, the biggest Median value increase (from 2 to 4) was observed in statement 1 (Reducing water consumption is necessary for sustainable development). The strongest agreement was expressed on the need to preserve the variety of living creatures (81\% compared to $72 \%$ before the experiment). In the cluster devoted to the social dimension the biggest increase in scores assigned by the students was fixed in statement 5 (about the necessity to respect human rights). This was also the statement to which the biggest number of students expressed their strongest agreement (Median $=5$ ). The number of students who agreed or strongly agreed with statements related to the economic sector also increased (by $6 \%, 12 \%$ and $6 \%$, respectively).

On the whole, in this category, the impact of learning was most strongly pronounced in the environmental dimension (the total Median increase $=3$ ). However, the students also expressed more concern of social and economic issues, especially, those related to the respect of human rights and wiping out poverty.

\section{Sustainability attitudes}

The analysis of the results showed that in seven out of nine items of Sustainability attitudes category $(10,12,13,14,16,17,18)$ the Median after the experimental learning was 4, which means that the majority of the students agreed with them. In items 11 (I think that we need stricter laws and regulations to protect the environment) and 15 (I think that women and men throughout the world must be given the same opportunities for education and employment), the Median was 3, which showed the neutral attitudes of the majority of respondents to these statements. When analysing the answers in this category we found a decrease in the percentage of those respondents who disagreed and strongly disagreed with all the statements. At the same time, we fixed an increase in the percentage of those who agreed and strongly agreed with them. However, the change in students' sustainability attitudes was less substantial than the change in their sustainability knowingness, which is evidenced by the fact that an increase in Median value was observed only in one item (\# 18) of this category, this also indicating that the increase in scores assigned by students to items of economic dimension was the highest. The IQR ranged from 1 or 2 before and after the experiment, which showed that the respondents' opinions did not differ significantly. 
Table 1. Students' sustainability consciousness before and after the experimental learning

\begin{tabular}{|c|c|c|c|c|c|c|c|c|c|c|c|c|c|c|}
\hline \multirow[b]{2}{*}{ STATEMENTS } & \multicolumn{2}{|c|}{$\begin{array}{l}\text { Strongly } \\
\text { disagree }\end{array}$} & \multicolumn{2}{|c|}{ Disagree } & \multicolumn{2}{|c|}{ Neutral } & \multicolumn{2}{|c|}{ Agree } & \multicolumn{2}{|c|}{$\begin{array}{l}\text { Strongly } \\
\text { agree }\end{array}$} & \multicolumn{2}{|c|}{ Median } & \multicolumn{2}{|c|}{ IQR } \\
\hline & 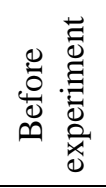 & 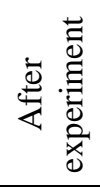 & 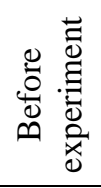 & 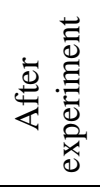 & 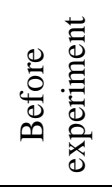 & 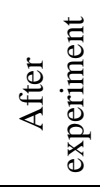 & 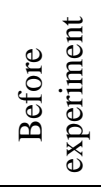 & 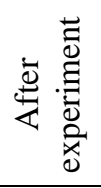 & 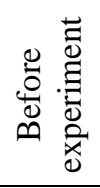 & 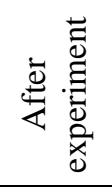 & 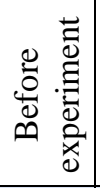 & 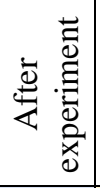 & 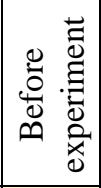 & 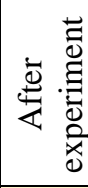 \\
\hline $\begin{array}{l}\text { SUSTAINABILITY KNOWINGNESS } \\
\text { Environmental } \\
\text { 1. Reducing water consumption is necessary for sustainable } \\
\text { development. }\end{array}$ & $\begin{array}{c}8 \\
24 \%\end{array}$ & $\begin{array}{c}1 \\
3 \%\end{array}$ & $\begin{array}{c}11 \\
33 \%\end{array}$ & $\begin{array}{c}6 \\
18 \%\end{array}$ & $\begin{array}{c}7 \\
21 \%\end{array}$ & $\begin{array}{c}7 \\
21 \%\end{array}$ & $\begin{array}{c}6 \\
18 \%\end{array}$ & $\begin{array}{c}10 \\
30 \%\end{array}$ & $\begin{array}{c}1 \\
3 \%\end{array}$ & $\begin{array}{c}9 \\
27 \%\end{array}$ & 2 & 4 & 1 & 2 \\
\hline $\begin{array}{l}\text { 2. Preserving the variety of living creatures is necessary for } \\
\text { sustainable development (preserving biological diversity). }\end{array}$ & $\begin{array}{c}0 \\
0 \% \\
\end{array}$ & $\begin{array}{c}1 \\
3 \% \\
\end{array}$ & $\begin{array}{c}4 \\
12 \% \\
\end{array}$ & $\begin{array}{c}2 \\
6 \% \\
\end{array}$ & $\begin{array}{c}5 \\
15 \% \\
\end{array}$ & $\begin{array}{c}3 \\
9 \% \\
\end{array}$ & $\begin{array}{c}14 \\
42 \% \\
\end{array}$ & $\begin{array}{c}13 \\
39 \% \\
\end{array}$ & $\begin{array}{c}10 \\
30 \% \\
\end{array}$ & $\begin{array}{c}14 \\
42 \% \\
\end{array}$ & 3 & 4 & 2 & 1 \\
\hline $\begin{array}{l}\text { 3. For sustainable development, people need to be educated in } \\
\text { how to protect themselves against natural disasters. }\end{array}$ & $\begin{array}{c}4 \\
12 \%\end{array}$ & $\begin{array}{c}1 \\
3 \%\end{array}$ & $\begin{array}{c}3 \\
9 \%\end{array}$ & $\begin{array}{c}2 \\
6 \%\end{array}$ & $\begin{array}{c}5 \\
15 \%\end{array}$ & $\begin{array}{c}5 \\
15 \%\end{array}$ & $\begin{array}{c}10 \\
30 \%\end{array}$ & $\begin{array}{c}13 \\
39 \%\end{array}$ & $\begin{array}{c}11 \\
33 \%\end{array}$ & $\begin{array}{c}12 \\
36 \%\end{array}$ & 4 & 4 & 2 & 1 \\
\hline $\begin{array}{l}\text { Social } \\
\text { 4. A culture where conflicts are resolved peacefully through } \\
\text { discussion is necessary for sustainable development. }\end{array}$ & $\begin{array}{c}4 \\
12 \%\end{array}$ & $\begin{array}{c}1 \\
3 \%\end{array}$ & $\begin{array}{c}1 \\
3 \%\end{array}$ & $\begin{array}{c}0 \\
0 \%\end{array}$ & $\begin{array}{c}3 \\
9 \%\end{array}$ & $\begin{array}{c}3 \\
9 \%\end{array}$ & $\begin{array}{c}12 \\
36 \%\end{array}$ & $\begin{array}{c}13 \\
39 \%\end{array}$ & $\begin{array}{c}13 \\
39 \%\end{array}$ & $\begin{array}{c}16 \\
48 \%\end{array}$ & 3 & 3 & 1 & 1 \\
\hline $\begin{array}{l}\text { 5. Respecting human rights is necessary for sustainable } \\
\text { development. }\end{array}$ & $\begin{array}{c}4 \\
12 \% \\
\end{array}$ & $\begin{array}{c}0 \\
0 \% \\
\end{array}$ & $\begin{array}{c}4 \\
12 \% \\
\end{array}$ & $\begin{array}{c}0 \\
0 \% \\
\end{array}$ & $\begin{array}{c}2 \\
6 \% \\
\end{array}$ & $\begin{array}{c}2 \\
6 \% \\
\end{array}$ & $\begin{array}{c}8 \\
24 \% \\
\end{array}$ & $\begin{array}{c}14 \\
42 \% \\
\end{array}$ & $\begin{array}{c}15 \\
45 \% \\
\end{array}$ & $\begin{array}{c}17 \\
51 \% \\
\end{array}$ & 4 & 5 & 1 & 1 \\
\hline $\begin{array}{l}\text { 6. To achieve sustainable development, all the people in the } \\
\text { world must have access to good education. }\end{array}$ & $\begin{array}{c}4 \\
12 \% \\
\end{array}$ & $\begin{array}{c}2 \\
6 \% \\
\end{array}$ & $\begin{array}{c}2 \\
6 \% \\
\end{array}$ & $\begin{array}{c}2 \\
6 \% \\
\end{array}$ & $\begin{array}{c}3 \\
9 \% \\
9\end{array}$ & $\begin{array}{c}2 \\
6 \% \\
\end{array}$ & $\begin{array}{c}12 \\
36 \% \\
\end{array}$ & $\begin{array}{c}14 \\
42 \% \\
\end{array}$ & $\begin{array}{c}12 \\
36 \% \\
\end{array}$ & $\begin{array}{c}13 \\
39 \% \\
\end{array}$ & 4 & 4 & 1 & 1 \\
\hline $\begin{array}{l}\text { Economic } \\
\text { 7. Sustainable development requires that companies act } \\
\text { responsibly towards their employees, customers and suppliers. }\end{array}$ & $\begin{array}{c}0 \\
0 \%\end{array}$ & $\begin{array}{c}0 \\
0 \%\end{array}$ & $\begin{array}{c}4 \\
12 \%\end{array}$ & $\begin{array}{c}2 \\
6 \%\end{array}$ & $\begin{array}{c}3 \\
9 \%\end{array}$ & $\begin{array}{c}3 \\
9 \%\end{array}$ & $\begin{array}{c}12 \\
36 \%\end{array}$ & $\begin{array}{c}12 \\
36 \%\end{array}$ & $\begin{array}{c}14 \\
42 \%\end{array}$ & $\begin{array}{c}16 \\
48 \%\end{array}$ & 4 & 4 & 1 & 2 \\
\hline $\begin{array}{l}\text { 8. Sustainable development requires a fair distribution of } \\
\text { goods and services among people in the world. }\end{array}$ & $\begin{array}{c}6 \\
18 \%\end{array}$ & $\begin{array}{c}0 \\
0 \%\end{array}$ & $\begin{array}{c}4 \\
12 \%\end{array}$ & $\begin{array}{c}2 \\
6 \%\end{array}$ & $\begin{array}{c}1 \\
3 \% \\
\end{array}$ & $\begin{array}{c}5 \\
15 \% \\
\end{array}$ & $\begin{array}{c}14 \\
42 \%\end{array}$ & $\begin{array}{c}12 \\
36 \%\end{array}$ & $\begin{array}{c}8 \\
24 \% \\
\end{array}$ & $\begin{array}{c}14 \\
42 \%\end{array}$ & 4 & 4 & 1 & 1 \\
\hline $\begin{array}{l}\text { 9. Wiping out poverty in the world is necessary for sustainable } \\
\text { development. }\end{array}$ & $\begin{array}{c}7 \\
21 \%\end{array}$ & $\begin{array}{c}2 \\
6 \%\end{array}$ & $\begin{array}{c}4 \\
12 \%\end{array}$ & $\begin{array}{c}4 \\
12 \%\end{array}$ & $\begin{array}{c}7 \\
21 \%\end{array}$ & $\begin{array}{c}6 \\
18 \%\end{array}$ & $\begin{array}{c}7 \\
21 \%\end{array}$ & $\begin{array}{c}12 \\
36 \%\end{array}$ & $\begin{array}{c}8 \\
24 \%\end{array}$ & $\begin{array}{c}9 \\
27 \%\end{array}$ & 3 & 4 & 2 & 2 \\
\hline $\begin{array}{l}\text { SUSTAINABILITY ATTITUDES } \\
\text { Environmental } \\
\text { 10. I think that using more natural resources than we need } \\
\text { threatens the health and well-being of people in the future. }\end{array}$ & $\begin{array}{c}5 \\
15 \%\end{array}$ & $\begin{array}{c}1 \\
3 \%\end{array}$ & $\begin{array}{c}3 \\
9 \%\end{array}$ & $\begin{array}{c}2 \\
6 \%\end{array}$ & $\begin{array}{c}3 \\
9 \%\end{array}$ & $\begin{array}{c}2 \\
6 \%\end{array}$ & $\begin{array}{c}15 \\
45 \%\end{array}$ & $\begin{array}{c}15 \\
45 \%\end{array}$ & $\begin{array}{c}7 \\
21 \%\end{array}$ & $\begin{array}{c}13 \\
39 \%\end{array}$ & 4 & 4 & 2 & 1 \\
\hline $\begin{array}{l}\text { 11. I think that we need stricter laws and regulations to protect } \\
\text { the environment. }\end{array}$ & $\begin{array}{c}4 \\
12 \% \\
\end{array}$ & $\begin{array}{c}1 \\
3 \% \\
\end{array}$ & $\begin{array}{c}3 \\
9 \% \\
\end{array}$ & $\begin{array}{c}1 \\
3 \% \\
\end{array}$ & $\begin{array}{c}8 \\
24 \% \\
\end{array}$ & $\begin{array}{c}7 \\
21 \% \\
\end{array}$ & $\begin{array}{c}9 \\
27 \% \\
\end{array}$ & $\begin{array}{c}12 \\
36 \% \\
\end{array}$ & $\begin{array}{c}9 \\
27 \% \\
\end{array}$ & $\begin{array}{c}12 \\
36 \% \\
\end{array}$ & 3 & 3 & 2 & 1.5 \\
\hline $\begin{array}{l}\text { 12. I think that it is important to take measures against } \\
\text { problems which have to do with climate change. }\end{array}$ & $\begin{array}{c}1 \\
3 \% \\
\end{array}$ & $\begin{array}{c}1 \\
3 \%\end{array}$ & $\begin{array}{c}4 \\
12 \% \\
\end{array}$ & $\begin{array}{c}2 \\
6 \%\end{array}$ & $\begin{array}{c}9 \\
27 \% \\
\end{array}$ & $\begin{array}{c}5 \\
15 \% \\
\end{array}$ & $\begin{array}{c}8 \\
24 \% \\
\end{array}$ & $\begin{array}{c}12 \\
36 \% \\
\end{array}$ & $\begin{array}{c}11 \\
33 \%\end{array}$ & $\begin{array}{c}13 \\
39 \% \\
\end{array}$ & 4 & 4 & 2 & 1 \\
\hline $\begin{array}{l}\text { Social } \\
13 \text {. I think that everyone ought to be given the opportunity to }\end{array}$ & $\begin{array}{c}2 \\
6 \%\end{array}$ & $\begin{array}{c}1 \\
3 \%\end{array}$ & $\begin{array}{c}2 \\
6 \%\end{array}$ & $\begin{array}{c}2 \\
6 \%\end{array}$ & $\begin{array}{c}6 \\
18 \%\end{array}$ & $\begin{array}{c}3 \\
9 \% \\
\end{array}$ & $\begin{array}{c}11 \\
33 \%\end{array}$ & $\begin{array}{c}12 \\
36 \%\end{array}$ & $\begin{array}{c}12 \\
36 \%\end{array}$ & $\begin{array}{c}15 \\
45 \%\end{array}$ & 4 & 4 & 1 & 2 \\
\hline
\end{tabular}




\begin{tabular}{|c|c|c|c|c|c|c|c|c|c|c|c|c|c|c|}
\hline $\begin{array}{l}\text { acquire the knowledge, values and skills that are necessary to } \\
\text { live sustainably. }\end{array}$ & & & & & & & & & & & & & & \\
\hline $\begin{array}{l}\text { 14. I think that we who are living now should make sure that } \\
\text { people in the future enjoy the same quality of life as we do } \\
\text { today. }\end{array}$ & $\begin{array}{c}3 \\
9 \%\end{array}$ & $\begin{array}{c}0 \\
0 \%\end{array}$ & $\begin{array}{c}4 \\
12 \%\end{array}$ & $\begin{array}{c}2 \\
6 \%\end{array}$ & $\begin{array}{c}7 \\
21 \%\end{array}$ & $\begin{array}{c}5 \\
15 \%\end{array}$ & $\begin{array}{c}11 \\
33 \%\end{array}$ & $\begin{array}{c}14 \\
42 \%\end{array}$ & $\begin{array}{c}8 \\
24 \%\end{array}$ & $\begin{array}{c}12 \\
36 \%\end{array}$ & 4 & 4 & 1 & 2 \\
\hline $\begin{array}{l}\text { 15. I think that women and men throughout the world must be } \\
\text { given the same opportunities for education and employment. }\end{array}$ & $\begin{array}{c}2 \\
6 \%\end{array}$ & $\begin{array}{c}1 \\
3 \%\end{array}$ & $\begin{array}{c}3 \\
9 \%\end{array}$ & $\begin{array}{c}2 \\
6 \%\end{array}$ & $\begin{array}{c}4 \\
12 \%\end{array}$ & $\begin{array}{c}3 \\
9 \%\end{array}$ & $\begin{array}{c}12 \\
36 \%\end{array}$ & $\begin{array}{c}12 \\
36 \%\end{array}$ & $\begin{array}{c}12 \\
36 \%\end{array}$ & $\begin{array}{c}15 \\
45 \%\end{array}$ & 3 & 3 & 1 & 1 \\
\hline $\begin{array}{l}\text { Economic } \\
\text { 16. I think that companies have a responsibility to reduce the } \\
\text { use of packaging and disposable articles. }\end{array}$ & $\begin{array}{c}4 \\
12 \%\end{array}$ & $\begin{array}{c}1 \\
3 \%\end{array}$ & $\begin{array}{c}4 \\
12 \%\end{array}$ & $\begin{array}{c}2 \\
6 \%\end{array}$ & $\begin{array}{c}4 \\
12 \%\end{array}$ & $\begin{array}{c}4 \\
12 \%\end{array}$ & $\begin{array}{c}10 \\
30 \%\end{array}$ & $\begin{array}{c}12 \\
36 \%\end{array}$ & $\begin{array}{c}11 \\
33 \%\end{array}$ & $\begin{array}{c}14 \\
42 \%\end{array}$ & 4 & 4 & 1 & 2 \\
\hline 17. I think it is important to reduce poverty. & $\begin{array}{c}5 \\
15 \% \\
\end{array}$ & $\begin{array}{c}0 \\
0 \% \\
\end{array}$ & $\begin{array}{c}2 \\
6 \% \\
\end{array}$ & $\begin{array}{c}3 \\
9 \% \\
\end{array}$ & $\begin{array}{c}4 \\
12 \% \\
\end{array}$ & $\begin{array}{c}6 \\
18 \% \\
\end{array}$ & $\begin{array}{c}11 \\
33 \% \\
\end{array}$ & $\begin{array}{c}12 \\
36 \% \\
\end{array}$ & $\begin{array}{c}11 \\
33 \% \\
\end{array}$ & $\begin{array}{c}12 \\
36 \% \\
\end{array}$ & 4 & 4 & 2 & 2 \\
\hline $\begin{array}{l}\text { 18. I think that companies in rich countries should give } \\
\text { employees in poor nations the same conditions as in rich } \\
\text { countries. }\end{array}$ & $\begin{array}{c}3 \\
9 \%\end{array}$ & $\begin{array}{c}0 \\
0 \%\end{array}$ & $\begin{array}{c}9 \\
27 \%\end{array}$ & $\begin{array}{c}5 \\
15 \%\end{array}$ & $\begin{array}{c}5 \\
15 \%\end{array}$ & $\begin{array}{c}3 \\
9 \%\end{array}$ & $\begin{array}{c}8 \\
24 \%\end{array}$ & $\begin{array}{c}15 \\
45 \%\end{array}$ & $\begin{array}{c}8 \\
24 \%\end{array}$ & $\begin{array}{c}10 \\
30 \%\end{array}$ & 3 & 4 & 2 & 1 \\
\hline $\begin{array}{l}\text { SUSTAINABILITY BEHAVIOUR } \\
\text { Environmental } \\
\text { 19. I recycle as much as I can. }\end{array}$ & $\begin{array}{c}4 \\
12 \%\end{array}$ & $\begin{array}{c}1 \\
3 \%\end{array}$ & $\begin{array}{c}5 \\
15 \%\end{array}$ & $\begin{array}{c}4 \\
12 \%\end{array}$ & $\begin{array}{c}11 \\
27 \%\end{array}$ & $\begin{array}{c}7 \\
21 \%\end{array}$ & $\begin{array}{c}13 \\
39 \%\end{array}$ & $\begin{array}{c}15 \\
45 \%\end{array}$ & $\begin{array}{c}2 \\
6 \%\end{array}$ & $\begin{array}{c}6 \\
18 \%\end{array}$ & 3 & 4 & 1.5 & 1 \\
\hline $\begin{array}{l}\text { 20. I always separate food waste before putting out the } \\
\text { rubbish when I have the chance. }\end{array}$ & $\begin{array}{c}4 \\
12 \% \\
\end{array}$ & $\begin{array}{c}3 \\
9 \% \\
\end{array}$ & $\begin{array}{c}10 \\
30 \% \\
\end{array}$ & $\begin{array}{c}8 \\
24 \% \\
\end{array}$ & $\begin{array}{c}9 \\
27 \% \\
\end{array}$ & $\begin{array}{c}6 \\
6 \% \\
\end{array}$ & $\begin{array}{c}8 \\
24 \% \\
\end{array}$ & $\begin{array}{c}10 \\
30 \% \\
\end{array}$ & $\begin{array}{c}2 \\
6 \% \\
\end{array}$ & $\begin{array}{c}6 \\
6 \% \\
\end{array}$ & 2 & 3 & 2 & 2 \\
\hline $\begin{array}{l}\text { 21. I have changed my personal lifestyle in order to reduce } \\
\text { waste (e.g., throwing away less food or not wasting materials). }\end{array}$ & $\begin{array}{c}3 \\
9 \%\end{array}$ & $\begin{array}{c}1 \\
3 \%\end{array}$ & $\begin{array}{c}8 \\
24 \%\end{array}$ & $\begin{array}{c}8 \\
24 \%\end{array}$ & $\begin{array}{c}5 \\
15 \%\end{array}$ & $\begin{array}{c}4 \\
12 \%\end{array}$ & $\begin{array}{c}11 \\
33 \%\end{array}$ & $\begin{array}{c}13 \\
39 \%\end{array}$ & $\begin{array}{c}6 \\
18 \%\end{array}$ & $\begin{array}{c}7 \\
21 \%\end{array}$ & 4 & 4 & 2 & 2 \\
\hline $\begin{array}{l}\text { Social } \\
\text { 22. When I use a computer or mobile to chat, to text, to play } \\
\text { games and so on, I always treat others as respectfully as I } \\
\text { would in real life. }\end{array}$ & $\begin{array}{c}3 \\
9 \%\end{array}$ & $\begin{array}{c}1 \\
3 \%\end{array}$ & $\begin{array}{c}7 \\
21 \%\end{array}$ & $\begin{array}{c}1 \\
3 \%\end{array}$ & $\begin{array}{c}3 \\
9 \%\end{array}$ & $\begin{array}{c}4 \\
12 \%\end{array}$ & $\begin{array}{c}13 \\
39 \%\end{array}$ & $\begin{array}{c}14 \\
42 \%\end{array}$ & $\begin{array}{c}7 \\
21 \%\end{array}$ & $\begin{array}{c}13 \\
39 \%\end{array}$ & 4 & 4 & 2 & 1 \\
\hline 23. I support an aid organisation or environmental group. & $\begin{array}{c}7 \\
21 \%\end{array}$ & $\begin{array}{c}5 \\
15 \%\end{array}$ & $\begin{array}{c}10 \\
30 \%\end{array}$ & $\begin{array}{c}9 \\
27 \%\end{array}$ & $\begin{array}{c}7 \\
21 \%\end{array}$ & $\begin{array}{c}9 \\
18 \%\end{array}$ & $\begin{array}{c}8 \\
24 \%\end{array}$ & $\begin{array}{c}10 \\
30 \%\end{array}$ & $\begin{array}{c}1 \\
3 \%\end{array}$ & $\begin{array}{c}3 \\
9 \%\end{array}$ & 2 & 3 & 2 & 2 \\
\hline $\begin{array}{l}\text { 24. I show the same respect to men and women, boys and } \\
\text { girls. }\end{array}$ & $\begin{array}{c}2 \\
6 \% \\
\end{array}$ & $\begin{array}{c}1 \\
3 \% \\
\end{array}$ & $\begin{array}{c}5 \\
15 \% \\
\end{array}$ & $\begin{array}{c}2 \\
6 \% \\
\end{array}$ & $\begin{array}{c}2 \\
6 \% \\
\end{array}$ & $\begin{array}{c}3 \\
9 \% \\
\end{array}$ & $\begin{array}{c}9 \\
27 \% \\
\end{array}$ & $\begin{array}{c}12 \\
36 \% \\
\end{array}$ & $\begin{array}{c}15 \\
45 \% \\
\end{array}$ & $\begin{array}{c}15 \\
45 \% \\
\end{array}$ & 4 & 4 & 2 & 1 \\
\hline $\begin{array}{l}\text { Economic } \\
25 . \text { I do things which help poor people. }\end{array}$ & $\begin{array}{c}3 \\
9 \% \\
\end{array}$ & $\begin{array}{c}2 \\
6 \% \\
\end{array}$ & $\begin{array}{c}10 \\
30 \% \\
\end{array}$ & $\begin{array}{c}5 \\
15 \% \\
\end{array}$ & $\begin{array}{c}10 \\
30 \% \\
\end{array}$ & $\begin{array}{c}10 \\
30 \% \\
\end{array}$ & $\begin{array}{c}8 \\
24 \% \\
\end{array}$ & $\begin{array}{c}12 \\
36 \% \\
\end{array}$ & $\begin{array}{c}2 \\
6 \% \\
\end{array}$ & $\begin{array}{c}4 \\
12 \% \\
\end{array}$ & 3 & 3 & 2 & 1 \\
\hline $\begin{array}{l}\text { 26. I often purchase second-hand goods over the internet or in } \\
\text { a shop. }\end{array}$ & $\begin{array}{c}1 \\
3 \%\end{array}$ & $\begin{array}{c}0 \\
0 \%\end{array}$ & $\begin{array}{c}10 \\
30 \%\end{array}$ & $\begin{array}{c}5 \\
15 \%\end{array}$ & $\begin{array}{c}11 \\
33 \%\end{array}$ & $\begin{array}{c}6 \\
18 \% \\
\end{array}$ & $\begin{array}{c}8 \\
24 \% \\
\end{array}$ & $\begin{array}{c}11 \\
33 \%\end{array}$ & $\begin{array}{c}3 \\
9 \% \\
\end{array}$ & $\begin{array}{c}11 \\
33 \%\end{array}$ & 3 & 4 & 2 & 2 \\
\hline $\begin{array}{l}\text { 27. I avoid buying goods from companies with a bad } \\
\text { reputation for looking after their employees and the } \\
\text { environment. }\end{array}$ & $\begin{array}{c}7 \\
21 \%\end{array}$ & $\begin{array}{c}3 \\
9 \%\end{array}$ & $\begin{array}{c}4 \\
12 \%\end{array}$ & $\begin{array}{c}4 \\
12 \%\end{array}$ & $\begin{array}{c}7 \\
21 \%\end{array}$ & $\begin{array}{c}6 \\
18 \%\end{array}$ & $\begin{array}{c}8 \\
24 \%\end{array}$ & $\begin{array}{c}11 \\
33 \%\end{array}$ & $\begin{array}{c}7 \\
21 \%\end{array}$ & $\begin{array}{c}8 \\
24 \%\end{array}$ & 3 & 4 & 2 & 1.3 \\
\hline
\end{tabular}




\section{Sustainability behaviour}

Besides the changes in students' sustainability knowingness and sustainability attitudes the survey also revealed changes in their sustainability behaviour. Like in the previous two categories, the number of those who strongly disagreed or disagreed with the statements of this category reduced after the experimental learning, while the number of those who agreed or strongly agreed - increased. However, it may be observed that after the experimental learning the increase in scores assigned by the students to the statements of the sustainability behaviour category was higher than the increase in scores assigned by them to the statements of the sustainability knowingness and sustainability attitudes categories. This is evidenced by the Median value increase in five items of this category (compared to the increase in four and one items in the sustainability knowingness and sustainability attitudes categories, respectively): 19 (recycling of wastes), 20 (separating food waste), 23 (supporting aid organisations or environmental groups), 26 (purchasing secondhand goods), 27 (avoiding buying goods from companies with a bad reputation). The dimension to which the engineering students assigned the lowest scores within this category was the social one, Median value increase being fixed in one item compared to two items in environmental and economic dimensions. Like in the previous two categories, the students' answers in the behaviour category did not indicate considerable divergence in opinions (the IQR ranging from 1 to 2 before and after the experiment).

\section{Discussion}

The results of our study which analysed the efficiency of online teaching sustainability at ESP classes on the whole showed an increase in undergraduate engineering students' knowingness of sustainable development issues and more responsible environmental attitudes and behaviours of students, as evidenced by their answers to a survey with the use of Likert scale questionnaire. The ESP course design permitted logical and organic integration of Sustainable Development issues based on an extensive body of resources and materials which students could explore and use in their study. The use of interactive presentation tools helped to make learning more interesting and participatory, stimulated students to active inquiry into the sustainability issues.

However, the impact of the learning was not equal in the three analysed areas (sustainability knowingness, sustainability attitudes and sustainability behaviour) and dimensions (environmental, social and economic). The learning produced the strongest impact on the sustainability knowingness and the sustainability behaviour of the students. The impact on the students' sustainability attitudes was less substantial. This means that, in case of our students, the increase in their knowledge of sustainability issues led to their more responsible sustainability behaviour but did not produce significant pro-environmental changes in their sustainability attitudes.

These findings are in line with those of Marcos-Merino, Corbacho-Cuello and Hernández-Barco (2020), which showed the direct correlation between the students' sustainability knowingness and sustainability behaviour and not in line with those obtained by Fielding and Head (2012) which found that the sustainability knowingness is not often reflected into people's responsible sustainability behaviour. Our results are particularly consistent with those reported by Levine and Strube (2012) who surveyed 90 college students about their knowledge of environmental issues and their pro-environment behaviours and attitudes and found that environmental knowledge significantly and independently predicted behaviour, however, was not significantly related to attitudes. Similarly, no association was found between knowledge and attitudes towards sustainable development in college students by Yavetz, Goldman and Pe'er (2009). In other studies (e.g. Marcos-Merino, Corbacho-Cuello \& Hernández-Barco, 2020), on the contrary, the positive association between the students' sustainability knowingness and sustainability attitudes was established.

We totally agree with those researchers (Marcos-Merino, Corbacho-Cuello \& Hernández-Barco, 2020; Robelia \& Murphy, 2012; Balakrishnan, Tochinai \& Kanemitsu, 2020; Lavrysh \& Lytovchenko, 2019) who experimentally prove the importance of education and its influence on individuals' sustainability consciousness and believe that teaching sustainability is essential if we look for behavioural changes in our students. We, particularly, support the conclusion made by Hines, Hungerford and Tomera (1987) that an individual cannot be concerned about the environment or act on a particular environmental problem if that individual does not know about the existence of the problem. This conclusion about the knowledge of the problem as a prerequisite to an action was based on the findings obtained by the authors as a result of their meta-analysis of 315 empirical studies of responsible environmental behaviour conducted over a period of ten years.

Our findings are also in accordance with those of Lyons and Breakwell (1994) who found that the key factor which discriminated against environmentally concerned and indifferent teenagers was the amount of knowledge about environmental issues they claimed to have. The positive correlation between the 
sustainability knowledge and the sustainability behaviorr was also fixed in the work of Robelia and Murphy (2012) who summarised 15 knowledge surveys in the United States and found that making informed pro-environmental decisions is difficult if an individual has incorrect or no knowledge. Thus, knowledge of sustainable development processes and their influence on human activities is important, especially to motivate changes in values, attitudes, and behaviorr associated with sustainable development (Arbuthnott, 2009).

Our analysis of different dimensions of sustainability consciousness of students showed that the dimension to which the engineering students assigned the highest scores, within the three analysed areas (sustainability knowledge, sustainability attitudes and sustainability behaviour), was the economic dimension, which is evidenced by the highest Median values in items corresponding to sustainability economic knowingness and attitudes. Following this dimension, they attributed similar values to environmental and social dimensions (Table 1). Comparison of these finding with those obtained in a similar study involving Spanish pre-service primary teachers (Marcos-Merino, Corbacho-Cuello \& HernándezBarco, 2020) showed that, unlike Ukrainian engineering students, they were more aware of social than economic and environmental sustainability issues.

\section{Limitations}

Our study has certain limitations regarding the characteristics of the sample of subjects. The number of participants involved in the research was limited. In addition, they were students of the same university in Ukraine, which significantly reduces the generalizability of the results of the study and the extrapolation of its conclusions to other contexts. It would be interesting to increase the sample, involving a bigger number of engineering students of several other Ukrainian universities in order to draw stronger conclusions.

\section{Conclusions}

The analysis of changes in different parameters of engineering students' sustainability consciousness showed the feasibility and appropriateness of teaching sustainability in ESP courses. The students' answers to the sustainability consciousness questionnaire showed an increase in their knowingness of issues of Sustainable Development and their more responsible environmental behaviour, which implies the importance of disseminating knowledge and educating people. One of the disciplines which have particularly strong potential for teaching sustainability is ESP since sustainability topics can be logically integrated into ESP design and the use of a wide range of resources and materials about Sustainable Development, the majority of which are in English, can contribute not only to Learning for Sustainability but also to language acquisition. The use of online presentation tools and a wide range of multimedia resources on their platforms makes the learning more interactive and motivating for students and stimulates them to an active inquiry into sustainability issues.

\section{References:}

Arbuthnott, K. D. (2009). Education for sustainable development beyond attitude change. International Journal of Sustainability in Higher Education, 10(2), 152-163. https://doi.org/10.1108/14676370910945954

Balakrishnan, B., Tochinai, F., \& Kanemitsu, H. (2020). Perceptions and Attitudes towards Sustainable Development among Malaysian Undergraduates. International Journal of Higher Education, 9(1), 44-51. https://doi.org/10.5430/ijhe.v9n1p44

Biasutti, M., \& Frate, S. (2017). A validity and reliability study of the Attitudes toward Sustainable Development scale. Environmental Education Research, 23(2), 214-230. https://doi.org/10.1080/13504622.2016.1146660

Boeve-de Pauw, J., Gericke, N., Olsson, D., \& Berglund, T. (2015). The Effectiveness of Education for Sustainable Development. Sustainability, 7(11), 15693-15717; https://doi.org/10.3390/su71115693

Buckler, C., \& Creech, H. (2014). Shaping the future we want. UN decade of Education for Sustainable Development (2005-2014). Final report. Paris, France: UNESCO. https://sustainabledevelopment.un.org/index.php?page=view\&type=400\&nr=1682\& menu=35

Cotton, D. R. E., Warren, M. F., Maiboroda, O., \& Bailey, I. (2007). Sustainable Development, Higher Education and Pedagogy: A Study of Lecturers' Beliefs and Attitudes. Environmental Education Research, 13(5), 579-597. https://doi.org/10.1080/13504620701659061

Fielding, K. S., \& Head, B. W. (2012). Determinants of young Australians' environmental actions: The role of responsibility attributions, locus of control, knowledge and attitudes. Environmental Education Research, 18, 171-186. https://doi.org/10.1080/13504622.2011.592936.

Gericke, N., Boeve-de Pauw, J., Berglund, T., \& Olsson, D. (2018) The Sustainability Consciousness Questionnaire: The theoretical development and empirical validation of an evaluation instrument for stakeholders working with sustainable development. Sustainable Development, 1-15. https://doi.org/10.1002/sd.1859

Grosseck, G., Tîru, L.G., \& Bran, R.A. (2019). Education for Sustainable Development: Evolution and Perspectives: A Bibliometric Review of Research, 1992-2018. Sustainability, 11, 6136. DOI:10.3390/su11216136

Hines, J., Hungerford, H. R., \& Tomera, A. N. (1987). Analysis and synthesis of research on responsible environmental behavior: A meta-analysis. Journal of Environmental Education, 18(2), 1-8. doi:10.1080/00958964.1987.9943482

Lavrysh, Y., \& Lytovchenko, I. (2019). The case of education for sustainable development approaches implementation at English language classes at the technical university in Ukraine. Pedagogika-Pedagogy, 91(5), $736-749$. 
https://pedagogy.azbuki.bg/en/pedagogics/pedagogyarticle/pedagogyarticle2016-4/the-case-of-education-for-sustainabledevelopment-approaches-implementation-at-english-language-classes-at-the-technical-university-in-ukraine/

Lavrysh, Y., Lytovchenko, I., \& Lukianenko, V. (2020). Ecocomposition Integration into ESP Course for Bachelors at a Technical University. The MEXTESOL Journal, 44(1), 1-16.

https://www.mextesol.net/journal/index.php?page=journal\&id_issue=175\#deb2bfa6fd9fc7910014e752018b6ecf

Levine, D. S., \& Strube, M. J. (2012). Environmental attitudes, knowledge, intentions and behaviors among college students. Journal of Social Psychology, 152, 308-326.

Lyons, E., \& Breakwell, G. M. (1994). Factors predicting environmental concern and indifference in 13- to 16-year-olds. Environment and Behavior, 26(2), 223-238. https://doi.org/10.1177/001391659402600205

Makrakis, V., \& Kostoulas-Makrakis, N. (2012). Course Curricular Design and Development of the M.Sc. Programme in the Field of ICT in Education for Sustainable Development. Journal of Teacher Education for Sustainability, 14 (2), 5-40. https://doi.org/10.2478/v10099-012-0007-7

Marcos-Merino, J. M., Corbacho-Cuello, I., \& Hernández-Barco, M. (2020). Analysis of Sustainability Knowingness, Attitudes and Behavior of a Spanish Pre-Service Primary Teachers Sample. Sustainability, 12(18), 7445. https://doi.org/10.3390/su12187445

Robelia, B., \& Murphy, T. (2012). What do people know about key environmental issues? A review of environmental knowledge surveys. Environmental Education Research, 18, 299-321. https://doi.org/10.1080/13504622.2011.618288

United Nations Educational, Scientific and Cultural Organization (UNESCO). (n.d.). ESD: Building a better, fairer world for the 21 st century. http://u4614432.fsdata.se/wp-content/uploads/2013/09/esd.pdf

WCED (1987). Report of the World Commission on Environment and Development: Our Common Future. Oxford, UK: Oxford University Press.

Yavetz, B., Goldman, D., \& Pe'er, S. (2009). Environmental literacy of pre-service teachers in Israel: A comparison between students at the onset and end of their studies. Environmental Education Research, 15(4), $393-415$. https://doi.org/10.1080/13504620902928422

Received: December 15, 3030 Accepted: March 26, 2021 